IZA DP No. 8593

The Impact of the German Autobahn Net on Regional Labor Market Performance:

A Study Using Historical Instrument Variables

Joachim Möller

Marcus Zierer

October 2014 


\title{
The Impact of the German Autobahn Net on Regional Labor Market Performance: A Study Using Historical Instrument Variables
}

\author{
Joachim Möller \\ Institute for Employment Research (IAB), \\ IZA and University of Regensburg
}

Marcus Zierer

University of Regensburg

Discussion Paper No. 8593

October 2014

\author{
IZA \\ P.O. Box 7240 \\ 53072 Bonn \\ Germany \\ Phone: +49-228-3894-0 \\ Fax: +49-228-3894-180 \\ E-mail: iza@iza.org
}

Any opinions expressed here are those of the author(s) and not those of IZA. Research published in this series may include views on policy, but the institute itself takes no institutional policy positions. The IZA research network is committed to the IZA Guiding Principles of Research Integrity.

The Institute for the Study of Labor (IZA) in Bonn is a local and virtual international research center and a place of communication between science, politics and business. IZA is an independent nonprofit organization supported by Deutsche Post Foundation. The center is associated with the University of Bonn and offers a stimulating research environment through its international network, workshops and conferences, data service, project support, research visits and doctoral program. IZA engages in (i) original and internationally competitive research in all fields of labor economics, (ii) development of policy concepts, and (iii) dissemination of research results and concepts to the interested public.

IZA Discussion Papers often represent preliminary work and are circulated to encourage discussion. Citation of such a paper should account for its provisional character. A revised version may be available directly from the author. 
IZA Discussion Paper No. 8593

October 2014

\section{ABSTRACT}

\section{The Impact of the German Autobahn Net on Regional Labor Market Performance: A Study Using Historical Instrument Variables}

This paper analyzes the impact of the German autobahn net on the economic performance of German regions. To address endogeneity and reverse causation problems, we use historical instrument variables, i.e. a plan of the railroad net in 1890 and a plan of the autobahn net in 1937. We find a statistically and economically significant causal effect of transport infrastructure investments as measured by changes in the length of the autobahn net of West German NUTS 3 areas on regional employment and the wage bill.

JEL Classification: L91, N73, N74, R11, R40, R49

Keywords: transport infrastructure, regional labor market performance,

historical instrumental variables, reverse causation, new economic geography

Corresponding author:

Joachim Möller

Institute for Employment Research (IAB)

Regensburger Str. 104

D-90478 Nürnberg

Germany

E-mail: joachim.moeller@iab.de 


\section{INTRODUCTION}

Investment in transport infrastructure aims to extend the radius of action for individuals and firms. Mobile consumers are closely linked to suppliers of goods and services. Through well-developed transportation systems, workers obtain access to workplaces and producers obtain access to their customers or suppliers. An efficient transportation net is a prerequisite for value-added chains that enable producers to use the advantages of specialization and the division of labor. Therefore, there are good reasons to assume that investment in transportation facilities is a major driver of regional economic growth. However, it is also true that transport facilities could ease the accessibility of the region for external producers. More competition might be detrimental to home producers, and the net effect of lower transportation costs is ambiguous. Studies on the relationship between transportation infrastructure and economic growth are plagued by a reverse causality problem. For example, a positive correlation between transport infrastructure and regional growth might exist because lower transportation costs spur regional growth, or because higher regional growth leads to a higher demand for transportation infrastructure. Empirical studies must take this issue into account.

The aim of the present paper is to contribute to a small but growing literature on the causal effect of infrastructure on economic growth at the regional level by using historic instrumental data. The approach is in the spirit of Duranton and Turner (2012), who investigate the causal effect of transport infrastructure on regional economic growth for the US. Their theoretical motivation relies on a model of city size. Here, we stress agglomeration and network effects through the accessibility of producers and consumers. Moreover, we test alternative specifications of the estimated equations and provide a battery of test statistics to scrutinize the assumptions underlying the instrumental variable approach. In general, our findings indicate that there is a sizable causal effect of public investment in the German autobahn network on future regional labor market performance. Extending the regional autobahn net by one standard deviation in the 1937 to 1994 period led to higher employment or wage bill growth in the period from 1994 to 2008 of $1.8-3$ and $2.7-4.3$ percentage points, respectively. The results are robust with respect to changes in the specification and estimation methods.

Several arguments underline the economic policy relevance of our investigation. The results could contribute to the debate on the importance of the size and quality of transport systems for the economy. Investment in the transport infrastructure makes up a material part of total public investment activities in Germany. Identifying the size of the effect of transportation investment on economic growth may serve as a guideline for public initiatives or public/private partnerships in an important field of public activities.

The remainder of the paper is organized as follows. In the next section, we summarize the results of previous studies. In section 3, we introduce a theoretical model that captures the interaction between investment in transport infrastruc- 
ture and economic performance as measured by regional employment or the wage bill. The theoretical approach is based on the concepts of the reachability and market potential of a location. Both depend on investment in transport infrastructure. The model serves as a foundation for the empirical specification. Section 4 describes the data and presents some descriptive evidence. As spatial units, we consider NUTS 3 areas $^{1}$. To address the reverse causality issue, we adopt an approach using historic instruments on regional railroads from 1890 and road networks from 1937. Section 5 contains the results of the econometric estimates, and Section 6 concludes.

\section{BACKGROUND}

Roughly three-quarters of the German population live in metropolitan areas, i.e., big cities and their surroundings within commuting distance (BBSR (2011)). The transport system is of paramount importance for the development and functioning of the economy within the spatial and settlement structures. This is especially true for manufacturing industries, which still play an important role in Germany. In many fields, such as the automotive industry, supply chains are a constituting element of industrial organization. Transport infrastructure is likely to influence the allocation of the working population as well as the location of firms.

\subsection{Previous theoretical approaches}

In regional research, the importance of transport and transport costs for economic development has been recognized since the early days (see, for instance, Thünen (1842)). Classical and New Economic Geography have shown that transport costs play a crucial role in shaping the spatial structure of the economy (e.g. Fujita et al. (1999)). In this context, we restrict ourselves to the impact of transport infrastructure on regional economic performance as measured by employment or the wage bill. Duranton and Turner (2012) investigate how changes in a city's supply of transportation infrastructure affect its growth. To clarify these effects, they develop a model describing the relationship between transport networks and urban population growth. The theory is structured along four equations. Foremost, they consider transport costs and population or employment in a static model of a monocentric city. In equilibrium, workers are indifferent between alternative locations. The authors assume that homogenous workers commute to a central business district (CBD) to earn their wage. Generally, the equilibrium population depends on the attractiveness of the city (e.g., regional wages and the city's value of amenities) and local transport costs. The fundamental idea is that commuting costs are directly related to the size of a city. Transferring the static model to a dynamic setting implies a convergence process.

${ }^{1}$ NUTS: fr. Nomenclature des Unités Territoriales Statistiques. 
The convergence to a steady state indicates that large cities grow more slowly than do smaller ones. Asymmetrically, cities larger than their steady state will decline slowly, and cities smaller than their steady state will grow relatively quickly. Third, transportation costs can be construed as a function of the transportation infrastructure and population. The relationship must satisfy the condition that commuting costs increase with population but decrease with the transportation infrastructure. Furthermore, transport costs can vary with local conditions.

\subsection{Previous empirical studies}

The interdependence of investments in infrastructure and regional economic growth has been noted in early research. Frey (1979), for instance, stresses the double character of public expenditure for infrastructure: on the one hand, it anticipates economic growth; on the other hand, it responds to economic growth. Hence, empirical studies that aim to identify the role transport plays for economic growth are plagued by endogeneity and reverse causality issues. Previous studies on the impact of infrastructure on regional economic development mainly consider output. In his pioneering work, Aschauer (1989) investigates the productive role of public investments from a more general perspective. His empirical approach is based on macroeconomic models with strongly aggregated data. A similar method is employed by Holtz-Eakin (1988), Munnell (1990)) and Ford and Poret (1991), who concentrate on transport infrastructure. A general problem in these early contributions is the neglect of the endogeneity issue, or the possibility that economic development influences investment in infrastructure.

More recent work attempts to address the endogeneity problem of public infrastructure through structural models (Bougheas et al. (2000)) or instrumental variables approaches (Calderon and Servén (2003)). Increasingly, panel data models are employed (Canning and Pedroni (2004)) through which dynamic effects can be captured (e.g. Hsiao and Shen (2003), Brülhart and Sbergami (2009)). It is increasingly acknowledged that the subject requires a disaggregated approach. This is due to the necessary variation for identifying statistical effects. As noted by Gramlich (1994), regional disaggregation enables a more detailed consideration of factors that are relevant for the growth of a location. In particular, the issue of endogeneity can be addressed more adequately with disaggregated data.

The studies by Anas (1981, 1982), Anas and Duann (1985) and McDonald and Osuji (1995) concentrate more on land use and the determination of land prices in suburbanization. Few papers address the interrelationship between transport infrastructure and changes in spatial structure and the distribution of wealth across space. In this context, Steen (1986) analyzes the interrelationship between transport networks and population in a polycentric spatial structure. Population density decreases with growing distance to a well-functioning transportation net. McMillen and McDonald (1998) support these results with respect to employment and the main road network. The study by Baum-Snow (2007) uses an 
instrumental variable approach and corroborates this analysis with respect to the U.S. interstate highway system. The outcome variable in this context is the population density within cities. It becomes evident that population density particularly increases in locations with close distance to express highways. This phenomenon might spur suburbanization processes. The author uses a specification in first differences. The results indicate that regions with better endowment in transport infrastructure exhibit higher population growth rates. The work of Baum-Snow (2007) shows a close relationship to the causal analysis of Duranton and Turner (2012). Both studies start from the fact that in a model of regional economic development, transport infrastructure is endogenous. The simultaneity issue is addressed by the use of instrumental variables. The central finding of Duranton and Turner (2012) is that a 10 percent increase in a city's initial stock of roads causes an approximately 2 percent increase in its population and employment over a 20 -year period.

\section{THEORETICAL CONSIDERATIONS}

\subsection{A New Economic Geography model}

Investment in the transport infrastructure of a location improves its reachability for other regions and its accessibility to other regions. A given location is embedded in a spatial structure that involves other locations at various distances and of various size. A suitable concept for capturing the spatial economic context of a location is the market potential as introduced by Harris (1954).

The market potential of region $r$ depends on the accessibility or reachability of regions in a wider economic space $S$ surrounding the firm's location as well as on the number and income of customers living there. According to Harris (1954), it can be defined as

$$
M_{r}:=\sum_{s \in S} Y_{s} f\left(d_{r, s}, I_{r, s}\right),
$$

where $Y_{s}$ is total income at location $s$ and $f(\cdot)$ is the distance deterrence function. The latter depends negatively on the distance $d_{r, s}$ and positively on the transport infrastructure $I_{r, s}$ between region $r$ and $s$. Hence, investment in infrastructure increases the market potential of a location.

The problem with Hanson's concept is that it is introduced in an ad hoc manner and not embedded in general equilibrium considerations. Hence, the theoretical justification appears to be weak prima facie. Hanson (2005), however, has emphasized that contributions in the field of New Economic Geography (NEG, see Fujita et al. (1999)) have offered a sound theoretical underpinning of (a modified) market potential concept. In the spirit of Hanson (2005), we follow this route. However, whereas Hanson is interested in the influence of regional structures such as agglomerations on the wage level, we stress the role of transport infrastructure for labor market performance. 
Define a composite consumption good $C$ as

$$
C=\left[\sum_{i=1}^{N} c^{\rho}\right]^{1 / \rho}
$$

with $\rho=(\sigma-1) / \sigma$. Let the utility function of a representative customer depend on a composite consumption good $C$ and housing services $H$

$$
U=C^{\mu} H^{1-\mu} .
$$

Hence, the expenditure shares of the composite consumption good and housing services are $\mu$ and $1-\mu$, respectively.

The firm produces output with labor as the only input. Through the network and knowledge spillover effects of firms in the neighborhood, there are positive external effects on productivity. A better transport infrastructure increases the accessibility of partners and leads to higher external effects, which fosters efficiency in production. We model this through an influence of transport infrastructure on fixed and variable labor requirements for an individual firm $i$ in region $r$ :

$$
\ell_{i r}=\underset{(-)}{\alpha_{r}\left(I_{r}\right)}+\underset{(-)}{\beta_{r}\left(I_{r}\right)} y_{i r}
$$

The individual firm faces marginal costs of

$$
c_{i r}=\beta_{r} w_{r},
$$

where $w_{r}$ is the local wage. Then, the profit-maximizing f.o.b. price for the firm is given in the usual way as a mark-up on marginal costs.

$$
p_{i r}^{*}=\frac{\sigma}{\sigma-1} \beta_{r} w_{r} .
$$

Using equations 3.4 and 3.6, one obtains for the optimal firm's profit in region $r$

$$
\pi_{i r}^{*}=p_{i r}^{*} y_{i r}-w_{r} \ell_{i r}=w_{r}\left(\frac{1}{\sigma-1} \beta_{r} y_{i r}-\alpha_{r}\right) .
$$

Free entry implies a zero profit condition; thus,

$$
y_{i r}^{*}=\frac{\alpha_{r}(\sigma-1)}{\beta_{r}} .
$$

For optimal employment of an individual firm, we have

$$
\ell_{i r}^{*}=\alpha_{r}+\beta_{r} y_{i r}^{*}=\alpha_{r} \sigma .
$$


Because all firms in region $r$ are identical by assumption,

$$
L_{r}=n_{r} \ell_{i r} \quad, \quad Y_{r}=n_{r} y_{i r} \quad \text { and } \quad P_{r}=p_{i r} \forall i, r .
$$

The c.i.f. price of region's $r$ goods in region $s$ is

$$
P_{r, s}=P_{r} T_{r, s} \text { with } T_{r, s}=T_{s, r}=\tau\left(d_{r, s}, I_{r}\right),
$$

where the transportation costs between $r$ and $s$ increase with distance, $d_{r, s}$, and decline with transport infrastructure $I_{r} .^{2}$ The general price level for manufacturing goods in region $r$ is

$$
P_{r}=\left[\sum_{s} n_{s} P_{s}^{-(\sigma-1)} \tau\left(d_{r, s}, I_{r}\right)^{-(\sigma-1)}\right]^{-1 /(\sigma-1)} .
$$

The price index of manufacturing goods, $P_{r}$, is higher for regions in the periphery where the lion's share of goods has to be imported from distant regions and lower for regions in the core, where many firms are located. It is evident from equation 3.12 that $P_{r}$ also increases with accessibility and declines with investment in transport infrastructure.

The total sales of region's $r$ manufacturing products are given as

$$
Y_{r}=\mu n_{r} \sum_{s} Y_{s}\left(\frac{P_{r, s}}{P_{s}}\right)^{1-\sigma}
$$

where $P_{s}$ and $Y_{s}$ are the general price level and total income in the target region $s$, respectively. With zero profits, the region's total wage bill $W_{r} L_{r}=W_{r} n_{r} \alpha_{r} \sigma$ must be equal to total manufacturing sales:

$$
Y_{r}=\mu n_{r} \sum_{s} Y_{s}\left(\frac{P_{r, s}}{P_{s}}\right)^{1-\sigma}=W_{r} n_{r} \alpha_{r} \sigma
$$

Solving for wages yields

$$
W_{r}=\frac{\mu}{\alpha_{r} \sigma} \sum_{s} Y_{s}\left(\frac{P_{r, s}}{P_{s}}\right)^{-(\sigma-1)} .
$$

Together with equations 3.7 and 3.11 , one obtains an equation similar to the one Hanson (2005) uses for investigating regional nominal wage-level effects:

$$
W_{r}=\left(\frac{\mu}{\alpha_{r}\left(I_{r}\right)}\right)^{1 / \sigma} \sigma^{-1}\left(\frac{\sigma-1}{\beta_{r}\left(I_{r}\right)}\right)^{(\sigma-1) / \sigma}\left[\sum_{s} Y_{s} P_{s}^{\sigma-1} \tau\left(d_{r, s}, I_{r}\right)^{-(\sigma-1)}\right]^{1 / \sigma} .
$$

\footnotetext{
${ }^{2}$ Of course, the infrastructure in $r$ and all other transport facilities between $r$ and $s$ matter;
} these are of no interest here. 
As Hanson (2005) points out, the right-hand side resembles a traditional market potential equation because wages in region $r$ are increasing with rising income in trading partner regions and their accessibility, as indicated by lower transport costs. However, as noted by Brakman et al. (2009) [p.237ff], the difference from the traditional market potential concept is that the square brackets on the righthand side of equation 3.16 additionally contain the price index of the partner regions. Hence, the concept should be addressed as the real instead of the nominal market potential. A lower price index in the trading partner's region indicates more competition. This could be interpreted as a deglomeration force as opposed to the agglomeration force of the nominal market potential effect.

In our extension of the model transport, one can derive from equation 3.16 that investment in local transport infrastructure increases the local wage level through three different channels. Local transport infrastructure lowers the constant and variable part of labor requirement per unit of the manufacturing good, as modeled in equation 3.9. Moreover, if the market access is improved, this leads to lower c.i.f. prices of the region's products. A counter-force comes into play if one considers not only the fact that a better infrastructure in region $r$ increases access to other regions but also that region $r$ can be accessed more easily by the partner regions. This implies higher competition in the home market. Considering the possibility of multiple equilibria in the NEG models (implying concentration as well as dispersion tendencies), the outcome of investment in infrastructure is theoretically ambiguous in general.

\subsection{General equilibrium conditions}

Equation 3.16 does not prevent a complete description of the model because it contains endogenous variables on the right-hand side. To complete the solution, consider that in spatial equilibrium, real wages in all regions must be equal:

$$
\frac{W_{r}}{P_{r}^{1-\mu} Q_{r}^{\mu}}=\frac{W_{s}}{P_{s}^{1-\mu} Q_{s}^{\mu}} \quad \forall r, s,
$$

where $Q_{r}$ is the price index for housing services in region $r$.

Let the total wage bill in the economy and in the region be denoted by $B$ and $B_{r}$, respectively. Total income is the sum of sales from manufacturing - or the total wage bill - and housing services:

$$
Y_{r}=B_{r}+H_{r} Q_{r} \quad \text { and } \quad Y=B+\sum_{r} H_{r} Q_{r} .
$$

The share of expenditures for housing services is $1-\mu$; hence,

$$
H_{r} Q_{r}=(1-\mu) Y_{r} .
$$

Total expenditures for housing services across all regions are

$$
\sum_{r} H_{r} Q_{r}=\frac{1-\mu}{\mu} B=\frac{1-\mu}{\mu} \sum_{r} n_{r} W_{r} \alpha_{r} \sigma
$$


The share of the regional labor force in total national labor force is $L_{r} / L$. This yields

$$
Y_{r}=B_{r}+\frac{1-\mu}{\mu} \frac{L_{r}}{L} \sum_{s} H_{s} Q_{s}=n_{r} \alpha_{r} \sigma\left(B_{r}+\frac{1-\mu}{\mu} \frac{1}{L} \sum_{s} n_{s} \alpha_{s} \sigma W_{s}\right) .
$$

Note that the number of housing units in a region equals the number of workers by assumption: $H_{r}=L_{r}$. The model gives an interdependent system of non-linear equations for four central unknown variables in each region. These variables are income $Y_{r}$, the price index, $P_{r}$, the number of firms $n_{r}$ and the wage level $W_{r}$. In equilibrium, the following conditions must hold for all regions:

$$
P_{r}=\left[\sum_{s} n_{s} \theta\left(\beta_{s} W_{s} T_{s, r}\right)^{-(\sigma-1)}\right]^{-1 /(\sigma-1)},
$$

$$
W_{r}=\left(\frac{\mu}{\alpha_{r}\left(I_{r}\right)}\right)^{1 / \sigma} \sigma^{-1}\left(\frac{(\sigma-1)}{\beta_{r}\left(I_{r}\right)}\right)^{(\sigma-1) / \sigma}\left[\sum_{s} Y_{s} P_{s}^{\sigma-1} T_{r, s}^{-(\sigma-1)}\right]^{1 / \sigma}
$$

and

$$
Y_{r}=n_{r} \alpha_{r}\left(I_{r}\right) \sigma\left(W_{r}+\frac{1-\mu}{\mu} \frac{\sigma}{L} \sum_{s} n_{s} \alpha_{s}\left(I_{s}\right) W_{s}\right)
$$

where $\theta:=\left(\frac{\sigma}{\sigma-1}\right)^{-(\sigma-1)}$ and $L$ is the aggregate labor supply. Moreover, $r-1$ equations can be derived from the fact that in equilibrium, real wages must be equal across regions:

$$
\frac{W_{r}}{P_{r}^{1-\mu}}\left(\frac{n_{r} \alpha_{r}\left(I_{r}\right)}{Y_{r}}\right)^{\mu}=\frac{W_{s}}{P_{s}^{1-\mu}}\left(\frac{n_{s} \alpha_{s}\left(I_{r}\right)}{Y_{s}}\right)^{\mu} \forall r, s .
$$

The final equation for determining the solution of the system is that the sum of regional employment must be equal to the aggregate labor supply:

$$
\sum_{r} L_{r}=\sum_{r} n_{r} \alpha_{r}\left(I_{r}\right) \sigma=L
$$

\subsection{From theory to empirics}

The structural general equilibrium model as outlined in the previous subsection is a highly non-linear interdependent model. We limit our interest to the analysis of a specific partial aspect of the model: the impact of public transport infrastructure investment $I_{r}$ on regional labor market outcomes. As discussed 
in the interpretation of equation 3.16, investment in transport infrastructure affects the regional wage level through different channels. If the competition effect is not dominant, we would expect the regional price level to fall and the wage level to rise with higher accessibility of the region. Although it is cushioned by the rise of the regional housing prices, an expected response would be growth of the regional labor force through inter-regional mobility and a subsequent rise in employment, $L_{r}$. If, however, the competition effect dominates, one would expect a decreasing number of jobs in the region. An analogous argument can be made for the regional wage bill, $B_{r}$.

Because the response of labor outcomes to investment in transport infrastructure is theoretically ambiguous, empirical analysis is needed. We therefore turn to the empirical part. We start from the fact that decisions on investments in public transport infrastructure are partly due to exogenous historical processes. For example, the railway and autobahn networks in the first half of the 20th century were significantly influenced by strategic military considerations. Hence, our identification strategy is based on historical data on regional transport networks, which we use as instruments.

\subsection{Empirical model}

As outlined in the theoretical model, labor market performance, as measured by indicator $V_{r t} \in\left(L_{r t}, B_{r t}\right)$, is influenced through various channels by investments in transport infrastructure $I_{r t}$. We aim to identify a causal effect of transport infrastructure on regional employment or the wage bill. In this way, our analysis is similar to the pioneering study of Duranton and Turner (2012) for the U.S. These authors use a specification in which the relative change in labor market performance, $\Delta \ln V_{r}$, is explained by the lagged level of this variable, the lagged level of infrastructure and controls. Our results with German data indicate that it might be preferable to relate changes in labor market performance to relative changes in transport infrastructure, where the latter is measured as the length of the express highway (autobahn) net in the specific region.

Our basic equation for estimation has the following form:

$$
\ln V_{r, t_{2}}-\ln V_{r, t_{1}}=a_{0}+a_{1} \ln V_{r, t_{1}}+a_{2}\left(\ln I_{r, t_{1}}-\ln I_{r, t_{0}}\right)+\mathbf{x}_{\mathbf{r}}^{\mathbf{1}} \beta^{\mathbf{1}}+\varepsilon_{r}^{1} .
$$

Here, the row vector $\mathbf{x}_{\mathbf{r}}^{\mathbf{1}}$ stands for a set of exogenous regional control variables with corresponding parameter vector $\beta_{\mathbf{r}}^{\mathbf{1}}$ and $\varepsilon_{r}^{1}$ for a stochastic disturbance with the usual characteristics. The corresponding equation for infrastructure investment is

$$
\ln I_{r, t_{2}}-\ln I_{r, t_{1}}=b_{0}+b_{1} \ln I_{r, t_{1}}+b_{2}\left(\ln V_{r, t_{2}}-\ln V_{r, t_{1}}\right)+\mathbf{x}_{\mathbf{r}}^{2} \beta^{2}+\varepsilon_{r}^{2} .
$$

The lagged relative change in infrastructure investment as an explanatory variable in equation 3.27 and the relative change of labor market of labor market performance in equation 3.28 must be considered endogenous. In equation 3.27, 
this is the case despite the assumed time lag in the infrastructure investment variable. The reason is that the size of the infrastructure investment between $t_{0}$ and $t_{1}$ may be influenced by expectations of future regional economic development.

The reduced form equation for the development of infrastructure investment is

$$
\ln I_{r, t_{1}}-\ln I_{r, t_{0}}=c_{0}+c_{1} \ln V_{r, t_{1}}+\mathbf{z}_{\mathbf{r}} \gamma+\mathbf{x}_{\mathbf{r}}^{\mathbf{3}} \beta^{\mathbf{3}}+\varepsilon_{r}^{3} .
$$

where $\mathbf{z}_{\mathbf{r}}$ is a vector of suitable (excluded) instrument variables.

The model must satisfy the relevance and exogeneity conditions:

$$
\begin{aligned}
\gamma & \neq 0 \\
\operatorname{cov}\left(z_{i r}, \varepsilon_{r}^{3}\right) & =0 \quad \forall i .
\end{aligned}
$$

We instrumented the lagged relative change in transport infrastructure, $\ln I_{r, t_{1}}$ $\ln I_{r, t_{0}}$, and the relative change in labor market performance, $\ln V_{r, t_{2}}-\ln V_{r, t_{1}}$, by historical variables. For information far back in history (for example, we used the year 1937 for the autobahn variable and the year 1890 for the railway variable), it seems unlikely that these variables are correlated with the error term in equations 3.27 and 3.28. Note that the specification of equation 3.28 can be motivated through saturation effects. It can be expected that infrastructure investment is lower the higher the initial level of transport infrastructure is. Hence, the coefficient $b_{2}$ should be negative.

\section{DATA AND DESCRIPTIVE EVIDENCE}

\subsection{Historical data on transport nets}

\subsubsection{The 1890 plan of the German railway net}

In the following, we make use of a plan of the German railroad network from 1890. The plan was digitized within NUTS 1 and NUTS 3 boundaries of 2008 (see Figure 1). The map shows that railway lines were planned according to a broad mixture of geographical conditions, the principle of federalism, and strategic economic and military aspects. The polycentric development is one of the basic tenets of today's infrastructure and regional politics. In contrast to other countries, such as France, the convergence of living conditions represents a basic principle in the German constitution and has long been a focus of German economic policy (Aubert and Stephan (2000)).

The exogeneity can be motivated by some historical facts. In 1870, Germany consisted of a confederation of 39 states. Thus, in the beginning, a German national railroad network (suggested by Friedrich List in 1833) could not be communicated. However, the founding of the German Customs Union effected increasing trade between the different states. The benefits of this development were recognized, and the expansion of the transport system became desirable. Therefore, 
the objective of building railroad lines was to connect cities and metropolitan areas as directly and practicably as possible to foster inter-regional trade in the short term. However, neither later population and employment growth nor the income development of modern cities were in the foreground of economic and infrastructure politics. It is extremely unlikely that the economic development of the second half of the 20th century was anticipated at that time. A comparison with List's suggestions shows that his blueprints were partly modified and greatly expanded. The 1890 railroad network -20 years after the creation of the Bismarckian empire - was extended to the East by approximately $15,000 \mathrm{~km}$. Some of these tracks were built to meet the requirements of expected economic growth at that time. However, an explicit intention to allow modern commuter traffic and goods exchange through low transport costs seems unlikely. The initial railway building boom in Germany - mostly initiated by private companies aimed for profits in a not too distant future. For this reason, the plan of network construction also shows the profitability of railroads at that time. If economic development phases are overshadowed by irrational acts of war, such as in the wars of 1864 (German-Danish), 1866 (Prussian-Austrian) and 1870-71 (GermanFrench), long-term economic plans do not make sense. It is also clear that the network of railroads had a military-strategic task, particularly with respect to the national defense. A prominent example is the railroad line around Berlin. The ring in the east was completed in 1872 , and the one in the west was completed in 1877 .

\subsubsection{The 1937 plan of the German autobahn system}

In the 1920s, north-south connections were planned and built. Initially, the Halle-Leipzig and Hamburg-Frankfurt-Basel sections were included in the autobahn construction programs. The expansion of the express highway network was legally adopted in 1933. The 1937 autobahn network (see Figure 2) shows (i) roads that were already built and (ii) sections that should be completed in the future with the highest priority. The route length for the realized and planned autobahn network amounted to more than $3,600 \mathrm{~km}$ in 1937 . The 1937 plan had an eminent influence on the current network of motorways. However, it seems rather unlikely that the planned network concepts of that time anticipated the future regional labor market development, commuting and goods exchange of the post-war economy. Contemporaneous economic activity as well as strategic military considerations clearly stood in the foreground. The latter is confirmed by the so-called "Brown Memorandum" (submitted by Inspector General of Road Constructions, Fritz Todt) (see Kornrumpf (1990)). The military-strategic importance of the autobahn network is demonstrated by the fact that it was explicitly considered in the Four-Year Plan from fall 1936. 


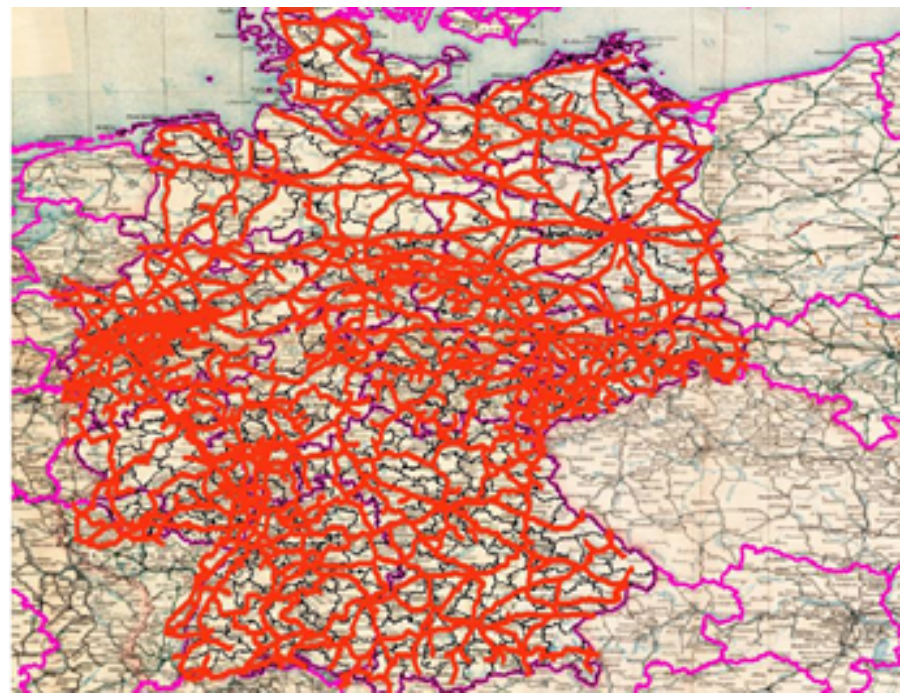

FigURE 1.- Digitized railroad network from 1890 within NUTS 1 and NUTS 3 boundaries of 2008

Notes: Source for the original: Geogr. lith. Inst. u. Steindr. v. W. Greve, Kgl. Hoflith, 13. 1890/1, Deutsche Bahn Museum. The total length of the digitized net is $28,536 \mathrm{~km}$.

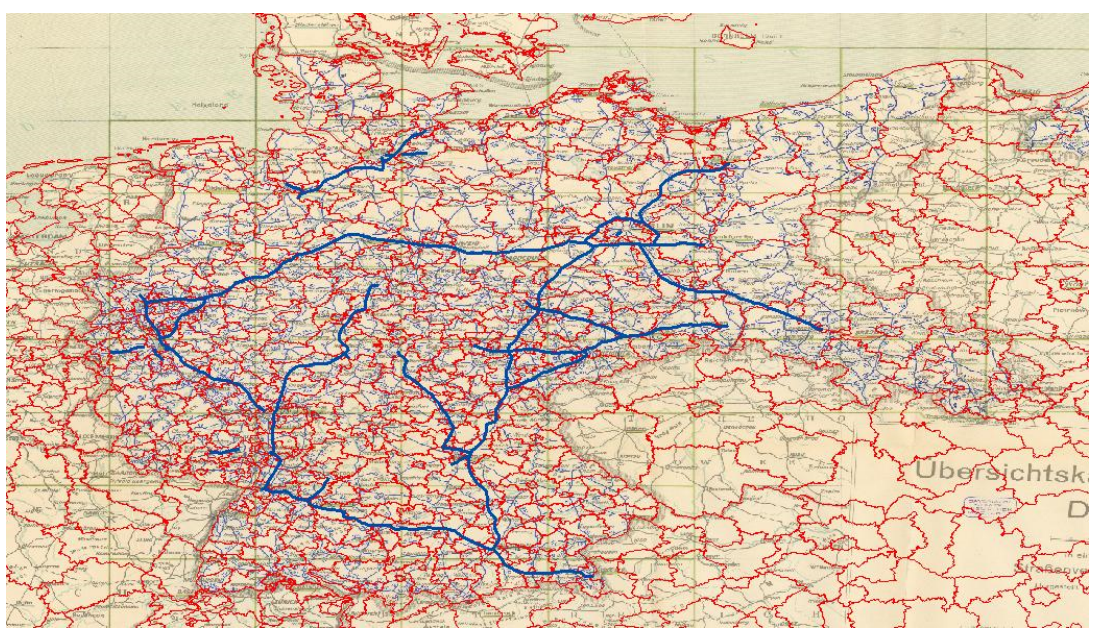

FiguRE 2.- Digitized autobahn network from 1937 within NUTS 3 boundaries of 2008 .

Notes: Source for the original: Reichsamt für Landesaufnahme, 1937. 


\subsection{Data and descriptive evidence}

To obtain a consistent data set, we adjusted socio-demographic, economic and infrastructure data in a adequate manner to the administrative territorial units at the NUTS 3 level of 2008. Historical infrastructure variables were obtained from historical maps. These maps were digitized and transformed into a graphical representation. With the help of a geo-information system, the information could be mapped to the modern administrative units.

For the outcome variables, employment growth and the growth of the total regional wage bill between 1994 and 2008 were chosen. We took 1994 as the starting point of the analysis because the first years after re-unification were characterized by extraordinary developments that affected population and employment. Furthermore, the large migration processes in the initial period after re-unification might have biased the results. For the same reason, we decided to only consider the time period before the Great Recession, which hit the German labor market in 2009.

As further control variables, we used historical population data for the years 1939, 1950, 1961 and 1970. Furthermore, the skill level of the work force might play a role in regional economic development. We therefore included the 1994 share of intermediate and highly skilled workers generated from data of the Institute for Employment Research (IAB). Moreover, we constructed seven $(0,1)$ dummy variables as controls for (slightly aggregated) federal states (laender) and eight $(0,1)$ dummy variables for types of regions ranging from metropolitan core cities to rural areas in the periphery. ${ }^{3}$

Table I presents some descriptive statistics for West German NUTS 3 regions. The average length and density of the autobahn net in the regions roughly quadrupled from 1937 to 2008, with the major change occurring before 1994. In 1937, 122 (37 percent) of regions at the NUTS 3 level had an autobahn within their area. This number increased to 291, or almost 90 percent, in 2008. However, there were still 35 regions without an autobahn running through their area at the end of our observation period. The region with the highest density (Hof) has almost $1.3 \mathrm{~km}$ of autobahn length per square kilometer of its area.

*** Include Table I about here $* * *$

\section{ESTIMATION RESULTS}

\subsection{Specification search and OLS results}

Because our infrastructure variable, autobahn in kilometers $\left(I_{t}\right)$, is equal to zero for a number of regions, we use two alternative ways of calculating the relative change. Both methods of calculating the growth rate led to similar results.

\footnotetext{
${ }^{3}$ The classification is taken from the Bundesamt für Bauwesen, Städtebau und Raumordnung in Bonn.
} 
The first way of handling the problem can be described as follows. We run a regression of $\ln I_{t-1}$ on $I_{t}$ for all cases where $I_{t-1}$ and $I_{t}$ are strictly positive. Then, the non-defined values $(\ln 0)$ in period $t-1$ are replaced by the fitted value of the regression. In an analogous way, a regression was run for the periods $t$ and $t+1$ to replace the non-defined values in period $t$.

The second method relies on a modified growth rate:

$$
\% \Delta_{t-1, t} I_{r}=\left\{\begin{array}{l}
\left(I_{r t}-I_{r, t-1}\right) / 0.5\left(I_{r t}+I_{r, t-1}\right) \\
0
\end{array}\right\} \quad \text { if } \quad I_{r t}+I_{r, t-1}\left\{\begin{array}{l}
>0 \\
=0
\end{array}\right\} .
$$

Because this method creates an artificial mass point of the distribution at $\hat{I}_{t}=2$, we introduced a $(0,1)$ dummy variable in the first-stage regression to capture the specific situation of regions that in 1937 or 1994, respectively, had no autobahn within their area. In a variant of our estimation approach, only the first dummy was used.

We used the OLS method to test for different specifications of the basic equation relating the change in labor market performance to the infrastructure variable and other controls. Without presenting the test results in detail, the findings can be summarized as follows:

- infrastructure variables are statistically highly significant, but only when introduced with a time lag;

- the hypothesis that the coefficients of the infrastructure variables add up to zero cannot be rejected; hence, a specification in changes rather than in levels is preferred;

- the same is true for the lagged population variables;

- initial human capital variables matter for the labor market development of the regions;

- dummies for the region type and the federal states are jointly significant;

- the (log of) the region's area is statistically significant in most specifications;

- a measure of the relative change of the infrastructure variable clearly outperforms a qualitative variable that indicates whether the region is related to the autobahn net.

We first present OLS results for a regression of growth of regional employment on infrastructure variables in the same specification as in Duranton and Turner (2012) and compare them with our own specification.

Table II presents the outcome of OLS estimations of employment growth. The comparison between the model of Duranton and Turner (2012) (Specification A) and the two variants of our model (Specification B for infrastructure measured in $\log$ differences and Specification $\mathrm{C}$ for infrastructure measured in modified growth rates) show qualitatively similar results. The adjusted coefficient of determination increases markedly when more control variables are included. At the same time, the estimated coefficients of the core explanatory variables tend to 
decrease. Note that the coefficients are relatively similar and statistically highly significant in all specifications. The coefficient of the initial employment level shows the expected negative sign and is always statistically significant. The estimated coefficient for the lagged dependent variable is statistically highly significantly positive and lies in the range between 0.3 and 0.5 .

$$
\text { *** Include Table II about here } * * *
$$

The results for the infrastructure equation are shown in Table III. The estimated coefficient of the infrastructure variable on the right-hand side of the equation is always negative and statistically significant at least at the $5 \%$ level -except for model 6 in specification $\mathrm{C}$, where it is statistically significant at the $10 \%$ level only. By contrast, neither in levels nor in growth rates is the estimated coefficient of the employment variable statistically significant at the $5 \%$ level. As in the employment equation, the adjusted coefficient of determination is increasing with the number of controls. The goodness of fit is markedly lower.

Overall, the OLS results indicate that the infrastructure variable has some influence on employment, whereas the influence on lagged employment on investment in the autobahn infrastructure, if anything, is weak. However, the results so far might be biased by the endogeneity of the infrastructure variable in the employment equation and vice versa. We therefore consider instrumental variable methods in the next subsection.

$$
\text { *** Include Table III about here *** }
$$

\subsection{Instrumental variable estimates}

In the following, we only consider the most comprehensive models, i.e., the models containing the full set of control variables. Table IV contains the results of the first-stage regressions where the endogenous regional transport infrastructure variable was regressed on the (the natural logarithm of) initial value of autobahn and federal roads (Reichsstraßen) kilometers in 1937 as well as the length of the railway system in 1890 . Additionally, the comprehensive set of control variables was included as well as a $(0,1)$ dummy variable to capture the situation in which the region had no autobahn connection in 1937 or in 1994, respectively. The latter variables were also tested in the structural equation but were found to be insignificant.

We see from Table IV that autobahn length in 1937 is significantly positive in the Duranton, Turner specification (columns 1 and 2) but significantly negative in the two alternative specifications. We interpret the latter as a saturation effect. The influence of the historical railway net variable is statistically significant positive at the $5 \%$ level except for the specification in column 5 . The adjusted $R^{2}$ exceeds 0.7 in the more comprehensive variants, i.e., in columns (2), (4) and $(6)$. 
When considering the test statistics in the lower panel of Table V, it appears that the variants with the extended set of instruments (Instr.2) are clearly preferable. Although the Angrist-Pischke and the Cragg-Donald test statistics support the relevance of the instruments in all cases, the null in the robust weak identification tests cannot be rejected in all specifications using the restricted set of instruments (Instr.1). Moreover, specification A appears to be problematic in both variants. Identification is weak when using the restricted set of instruments, whereas in the estimates using the extended set of instruments, the Hanson test rejects the hypothesis that the instruments are uncorrelated with the residuals. Hence, we conclude that specifications $\mathrm{B}$ and $\mathrm{C}$ are more suitable.

With regard to the estimated coefficients, one can observe that the coefficient of the autobahn variable is higher when the extended set of instruments is used. In the preferred variant, the estimated coefficient is roughly 2 in specification $B$ and roughly 3 in specification $\mathrm{C}$. Both estimates are statistically highly significant. The coefficient of the lagged endogenous variable is highly significantly negative, whereas the coefficient of the lagged growth rate of employment is positive, indicating some sluggishness in the process of adjusting regional employment. The human capital variables are also highly statistically significant and all carry a positive sign. Hence, regions with more human capital per employee in the initial period had better performance thereafter.

Interestingly, we find evidence for a correlation between the explanatory infrastructure variable and the disturbance term only in the model in column (1), which we disregard for other reasons. The null of exogeneity of the autobahn variable cannot be rejected in all variants of the model shown in columns (2) to (6). Hence, it would be justified to return to the OLS results because these estimates are more efficient.

$$
\text { *** Include Table IV about here *** }
$$

*** Include Table $\mathrm{V}$ about here ${ }^{* * *}$

\subsection{Results for the impact of the regional autobahn net on the wage bill}

The effects of the growth in transport infrastructure - as measured by autobahn kilometers - on the total regional wage bill are estimated in an analogous way as described in the last two subsections. Table VI presents the results for the OLS specifications. In contrast to the findings for the employment growth variable, the estimated coefficient for the autobahn variable tends to increase in all specifications when more control variables are introduced.

The coefficient of infrastructure is always positive. It is statistically highly significant in all variants of specifications B and C, whereas this is the case only in the models with a more comprehensive set of control variables in specification A. In the preferred models in column (6), the coefficient of the infrastructure 
variable on regional wage bill growth lies in the range between 2.0 (specification A) and 4.4 (specification C). It is somewhat puzzling that the coefficient of the lagged regional wage bill is positive in all variants. This finding indicates divergence of the total regional wage bill distribution. The choice of other control variables has a relatively small influence on the results.

Again, the IV approach passes all relevant test statistics. The instruments are powerful, and there is no indication that the residuals are correlated with the instruments. The impact of the growth in autobahn kilometers on the wage bill is estimated to be between 0.38 and 0.51 . According to our analysis, the causal effect of infrastructure on the regional wage bill is in the order of magnitude of 0.47 . This result implies that an increase in the autobahn length of one standard deviation led to an additional increase in the regional wage bill of roughly 2.3 percentage points in the 1994-2008 period. The effect obtained from the IV estimation is approximately $60 \%$ smaller than the OLS estimate. However, it is still statistically highly significant.

A comparison of results for our two basic variants of the estimation indicate that the effect of infrastructure on regional employment performance tends to be higher than that for employment growth. As argued in the theoretical part of the paper, this must be expected because the effect of infrastructure on wages is positive.

$$
\text { *** Include Table VI about here } * * *
$$

We also ran IV regressions using the same two sets of instruments as in the estimates for regional employment growth. Table VII contains the results, which are qualitatively similar to those for employment growth. Again, the identification is stronger according to the Anderson-Rubin and the Stock-Wright tests when the extended set of control is used. Specification A yields a negative $R^{2}$ and a negative sign for the infrastructure variable in column (1). The variant in column (2), however, seems to violate the uncorrelatedness condition. Specifications $\mathrm{B}$ and $\mathrm{C}$ perform better, and the instruments appear stronger in both variants. The over-identification test does not reject uncorrelatedness, at least when using the extended set of instruments. Specification $\mathrm{C}$ in this variant yields the highest coefficient of determination and seems to be the preferable model (column (6)). As in the OLS estimates, the dependent variable in levels has a positive sign. The lagged dependent variable exhibits a statistically highly significant positive coefficient, indicating some sluggishness in the development of the regional wage bill. Note that the human capital variables do not seem to have an important influence.

In addition to the OLS and 2SLS estimates, we used a robust GMM and LIML estimator. As the overview in Table VIII shows, the different estimators yield similar results. With the estimated coefficients, we calculated the impact of a one standard deviation increase of the autobahn variable on the growth of regional employment and the total wage bill. Several points must be mentioned. 
The differences between specifications $\mathrm{B}$ and $\mathrm{C}$ are small. With the extended set of instruments, all coefficients are positive, statistically highly significant and very close to the OLS results. Furthermore, for the restricted set of instruments, we find positive and significant effects that are somewhat lower than the OLS estimates. Depending on the specification or the estimation method, one standard deviation of the infrastructure variable leads to higher regional employment growth of between 1.8 and 3 percentage points in the 1994 to 2008 period. The corresponding impact on the total regional wage bill is between 2.7 and 4.3 percentage points. The higher effect for the total wage bill implies that an increase in the regional autobahn net led not only to more employment but also to higher wages.

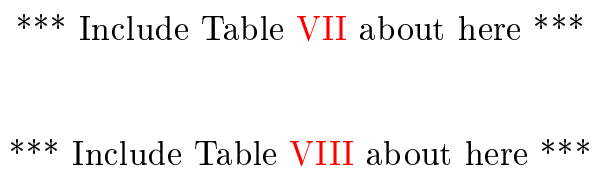

\section{CONCLUSIONS}

This paper investigates a causal effect of investment in transport infrastructure - particularly in the autobahn net - on regional labor market performance. We first present a theoretical model in the spirit of New Economic Geography that explicitly includes regional heterogeneity with respect to transport infrastructure. We argue that in addition to a direct effect on the transportation of final goods and corresponding market potential effects, there are positive effects of the regional transport system on the efficiency of production.

The theoretical reasoning leads to a highly interdependent non-linear model that cannot be estimated directly. However, the model is able to clarify the different channels by which transport costs are related to labor market performance. It is important to note that the theoretical model is ambiguous with respect to the impact of transport infrastructure on regional labor market performance. Hence, empirical analysis is required.

We concentrate on a specific part of the German transport infrastructure, the autobahn net. An autobahn connection leads to a considerable increase in the accessibility of the region and lower transport costs. Specification tests suggest that changes in the autobahn net affect regional labor market performance only with a time lag. Moreover, it seems that changes in regional employment or the total regional wage bill are related to changes in transport infrastructure, not its level.

In the regression analysis, a crucial problem is the possible endogeneity of transport infrastructure investments. Hence, a region might be chosen to obtain an autobahn connection if it is expected to become an economically successful area in the future. To address the endogeneity issue, we rely on a strategy with historical instrumental variables. These are taken from historical plans for auto- 
bahns and railway tracks and were digitized and related to the NUTS 3 areas of today.

The instrumental variable approach turns out to be successful. According to the corresponding test statistics, we can show that in our preferred specifications, the instruments are relevant and uncorrelated with the residuals. Moreover, the strategy allows us to test for the exogeneity of the autobahn variable in the employment and wage bill equations. According to the test statistics, exogeneity cannot be rejected in our preferred specification variants. This finding is supported by the small differences between the OLS and the IV estimates.

According to our estimates, an increase in autobahn length of one standard deviation in the 1937 to 1994 period leads to higher employment growth between 1.8 and 3 percentage points and to higher total growth of the wage bill between 2.7 and 4.3 percentage points in the 1994 to 2008 period. We therefore conclude that higher accessibility and lower transport costs through a more extensive autobahn net are beneficial to the regional labor market performance. 


\section{REFERENCES}

Anas, Alex, "The estimation of multinomial Logit models of joint location and mode choice from aggregated data.," Journal of Regional Science, 1981, 21, 223-242.

, Residential Location Markets and Urban Transportation: Economic Theory, Econometrics and Policy Analysis with Discrete Choice Models, Oxford: Academic Press., 1982. and Liang Shyong Duann, "Dynamic forecasting of travel demand, residential location and land development," Papers of the Regional Science Association, 1985, 56 (1), $37-58$.

Aschauer, David Alan, "Is public expenditure productive?," Journal of Monetary Economics, March 1989, 23 (2), 177-200.

Aubert, S. and A. Stephan, "Regionale Infrastrukturpolitik und ihre Auswirkung auf die Produktivität: Ein Vergleich von Deutschland und Frankreich," Discussion Papers, Wissenschaftszentrum Berlin für Sozialforschung, Deutsches Institut für Wirtschaftsforschung 2000.

Baum-Snow, Nathaniel, "Did highways cause suburbanization?," The Quarterly Journal of Economics, 2007, 122 (2), 775-805.

BBSR, "Stadtansichten: Befunde der BBSR-Umfrage aus Groß- und Mittelstädten," July 2011.

Bougheas, Spiros, Panicos O Demetriades, and Theofanis P Mamuneas, "Infrastructure, specialization, and economic growth," Canadian Journal of Economics, 2000, 33 (2), 506-522.

Brakman, Steven, Harry Garretsen, and Charles van Marrewijk, The New Introduction to Geographical Economics number 9780521875325. In 'Cambridge Books.', Cambridge University Press, April 2009.

Brülhart, Marius and Federica Sbergami, "Agglomeration and growth: Cross-country evidence," Journal of Urban Economics, 2009, 65 (1), 48-63.

Calderon, César and Luis Servén, "The output cost of Latin America's infrastructure gap," in William Easterly and Luis Serven, eds., The Limits of Stabilization: Infrastructure, Public Deficits, and Growth in Latin America, Stanford University Press, 2003, pp. 95-118.

Canning, David and Peter Pedroni, "The effect of infrastructure on long run economic growth," 2004.

Duranton, Gilles and Matthew A Turner, "Urban growth and transportation," The Review of Economic Studies, 2012, 79 (4), 1407-1440.

Ford, Robert and Pierre Poret, Infrastructure and private-sector productivity number 91. In 'Working Paper - Economic Series.', OECD Paris, 1991.

Frey, René Leo, Die Infrastruktur als Mittel der Regionalpolitik: Eine wirtschaftstheoretische Untersuchung zur Bedeutung der Infrastrukturförderung von entwicklungsschwachen Regionen in der Schweiz, Vol. 1 of Publikationen des Schweizerischen Nationalfonds aus den Nationalen Forschungsprogrammen, Bern: Haupt, 1979.

Fujita, Masahisa, Paul R. Krugman, and Anthony Venables, The Spatial Economy: Cities, Regions and International trade, Cambridge and Mass: MIT Press, 1999.

Gramlich, Edward M, "Infrastructure investment: A review essay," Journal of Economic Literature, 1994, 32 (3), 1176-1196.

Hanson, Gordon H., "Market potential, increasing returns and geographic concentration," Journal of International Economics, 2005, 67 (1), 1-24.

Harris, C. D., "The market as a factor in the localization of industry in the United States," Annals of the Association of American Geographers, 1954, 44, 315-348.

Holtz-Eakin, D., "Private Output, Government Capital, And The Infrastructure Crisis," Discussion Papers 1988-08, Columbia University, Department of Economics 1988.

Hsiao, Cheng and Yan Shen, "Foreign Direct Investment and Economic Growth: The Importance of Institutions and Urbanization*," Economic Development and Cultural Change, 2003, 51 (4), 883-896.

Kornrumpf, M., HAFRABA e. V., Deutsche Autobahn-Planung 1926-1934. 1990.

McDonald, J. F. and C. I. Osuji, "The effect of anticipated transportation improvement on residential land values," Regional Science and Urban Economics, 1995, 25 (3), 261-278. 
McMillen, Daniel P. and John F. McDonald, "Suburban Subcenters and Employment Density in Metropolitan Chicago," Journal of Urban Economics, March 1998, 43 (2), 157180.

Munnell, Alicia H., "Why has productivity growth declined? Productivity and public investment," New England Economic Review, Jan 1990, 30, 3-22.

Steen, Robert C, "Nonubiquitous transportation and urban population density gradients," Journal of Urban Economics, 1986, 20 (1), 97-106.

Thünen, Johann H. Von, Der isolirte Staat in Beziehung auf Landwirthschaft und Nationalökonomie, neu hrsg. von Walter Braeuer u. Eberhard E. A. Gerhardt 1966 ed. 1842. 
THE AUTOBAHN NET AND LABOR MARKET PERFORMANCE

TABLE I

Descriptive Statistics for the Development of Transport Infrastructure of West German NUTS-3-Regions

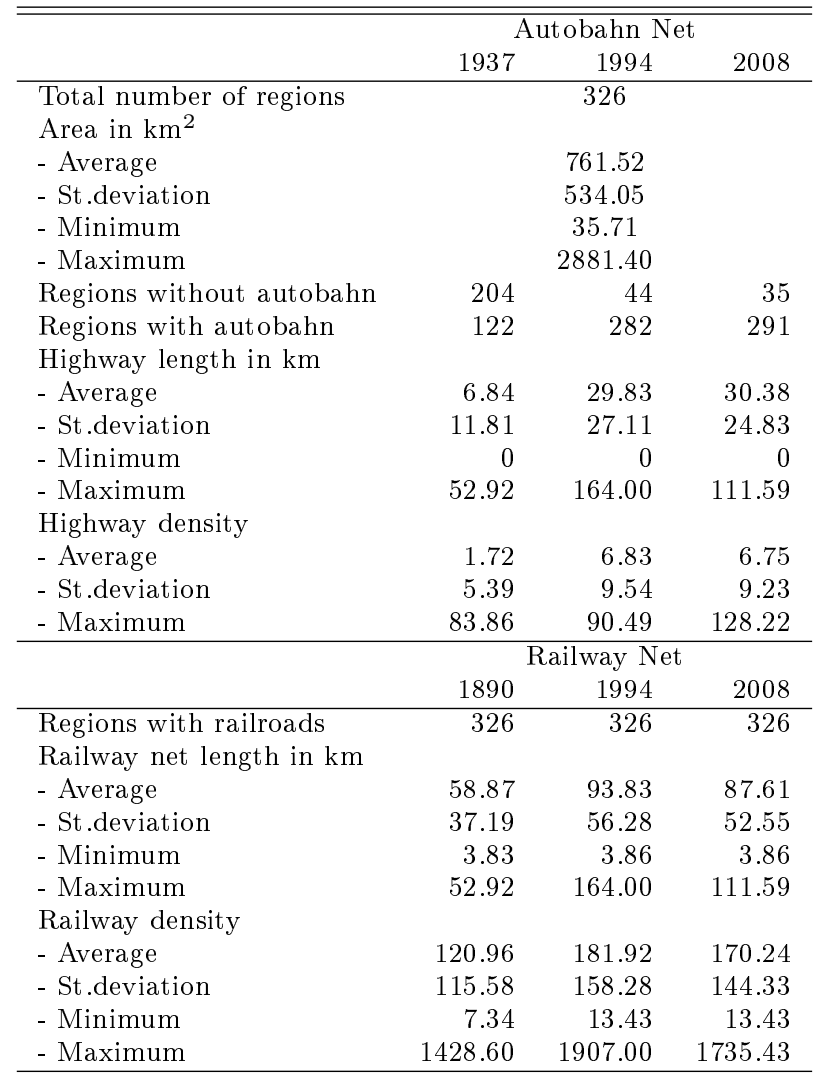

Notes: Highway (railway) density is calculated as autobahn (railway) length in $\mathrm{km}$ per 100 $\mathrm{km}^{2}$. 
TABLE II

Employment Growth 1994 to 2008 and the Regional Autobahn Net (OLS Estimates for 326 West German Regions)

\begin{tabular}{|c|c|c|c|c|c|c|}
\hline & \multicolumn{6}{|c|}{$\overline{\text { Dependent variable: } \Delta_{94,08} \ln L_{r}}$} \\
\hline & (1) & $(2)$ & (3) & (4) & (5) & (6) \\
\hline \multirow{3}{*}{ ln Autobahn 1994} & \multicolumn{6}{|c|}{ Specification A } \\
\hline & $2.252^{a}$ & $2.051^{a}$ & $1.826^{a}$ & $1.622^{a}$ & $1.626^{a}$ & $1.765^{a}$ \\
\hline & $(0.447)$ & $(0.422)$ & $(0.413)$ & $(0.415)$ & $(0.438)$ & $(0.460)$ \\
\hline \multirow[t]{2}{*}{ ln Empl.1994 } & $-3.141^{a}$ & $-4.213^{a}$ & $-4.149^{a}$ & $-4.804^{a}$ & $-5.021^{a}$ & $-5.425^{a}$ \\
\hline & $(0.733)$ & $(0.715)$ & $(0.835)$ & $(0.890)$ & $(1.109)$ & $(1.262)$ \\
\hline \multirow{2}{*}{$\Delta_{80,94} \ln$ Empl. } & $0.443^{a}$ & $0.401^{a}$ & $0.384^{a}$ & $0.353^{a}$ & $0.356^{a}$ & $0.340^{a}$ \\
\hline & $(0.040)$ & $(0.054)$ & $(0.052)$ & $(0.054)$ & $(0.055)$ & $(0.059)$ \\
\hline \multirow[t]{2}{*}{ Adj. $R^{2}$} & 0.369 & 0.418 & 0.428 & 0.436 & 0.441 & 0.475 \\
\hline & \multicolumn{6}{|c|}{ Specification B } \\
\hline \multirow[t]{2}{*}{$\Delta_{37,94} \ln$ Autob. } & $2.578^{a}$ & $2.389^{a}$ & $2.238^{a}$ & $2.080^{a}$ & $2.068^{a}$ & $2.028^{a}$ \\
\hline & $(0.357)$ & $(0.350)$ & $(0.324)$ & $(0.334)$ & $(0.348)$ & $(0.358)$ \\
\hline \multirow[t]{2}{*}{ ln Empl.1994 } & $-2.059^{a}$ & $-3.150^{a}$ & $-3.334^{a}$ & $-3.939^{a}$ & $-4.371^{a}$ & $-4.549^{a}$ \\
\hline & $(0.620)$ & $(0.626)$ & $(0.735)$ & $(0.847)$ & $(1.104)$ & $(1.211)$ \\
\hline \multirow{2}{*}{$\Delta_{80,94} \ln$ Empl. } & $0.478^{a}$ & $0.418^{a}$ & $0.399^{a}$ & $0.373^{a}$ & $0.379^{a}$ & $0.354^{a}$ \\
\hline & $(0.039)$ & $(0.050)$ & $(0.048)$ & $(0.051)$ & $(0.052)$ & $(0.056)$ \\
\hline \multirow[t]{2}{*}{ Adj. $R^{2}$} & 0.405 & 0.449 & 0.459 & 0.463 & 0.469 & $0.495^{\prime}$ \\
\hline & \multicolumn{6}{|c|}{ Specification $\mathrm{C}$} \\
\hline \multirow[t]{2}{*}{$\% \Delta_{37,94}$ Autob. } & $3.926^{a}$ & $3.649^{a}$ & $3.363^{a}$ & $3.167^{a}$ & $3.179^{a}$ & $3.074^{a}$ \\
\hline & $(0.557)$ & $(0.565)$ & $(0.527)$ & $(0.532)$ & $(0.561)$ & $(0.576)$ \\
\hline \multirow[t]{2}{*}{ ln Empl.1994 } & $-1.360^{a}$ & $-2.433^{a}$ & $-2.402^{a}$ & $-3.248^{a}$ & $-4.118^{a}$ & $-4.269^{a}$ \\
\hline & $(0.625)$ & $(0.636)$ & $(0.743)$ & $(0.867)$ & $(1.102)$ & $(1.201)$ \\
\hline \multirow[t]{2}{*}{$\Delta_{80,94} \ln$ Empl. } & $0.513^{a}$ & $0.440^{a}$ & $0.421^{a}$ & $0.386^{a}$ & $0.395^{a}$ & $0.370^{a}$ \\
\hline & $(0.039)$ & $(0.048)$ & $(0.047)$ & $(0.050)$ & $(0.051)$ & $(0.056)$ \\
\hline Adj. $R^{2}$ & 0.408 & 0.450 & 0.458 & 0.466 & 0.473 & 0.497 \\
\hline \multicolumn{7}{|l|}{ Controls } \\
\hline Hist. Popul. & $\mathrm{N}$ & $\mathrm{Y}$ & $\mathrm{Y}$ & $\mathrm{Y}$ & $\mathrm{Y}$ & $\mathrm{Y}$ \\
\hline Human Capital & $\mathrm{N}$ & $\mathrm{N}$ & $\mathrm{Y}$ & $\mathrm{Y}$ & $\mathrm{Y}$ & $\mathrm{Y}$ \\
\hline ln Area & $\mathrm{N}$ & $\mathrm{N}$ & $\mathrm{N}$ & Y & $\mathrm{Y}$ & $\mathrm{Y}$ \\
\hline Region Types & $\mathrm{N}$ & $\mathrm{N}$ & $\mathrm{N}$ & $\mathrm{N}$ & $\mathrm{Y}$ & $\mathrm{Y}$ \\
\hline Federal States & $\mathrm{N}$ & $\mathrm{N}$ & $\mathrm{N}$ & $\mathrm{N}$ & $\mathrm{N}$ & $\mathrm{Y}$ \\
\hline
\end{tabular}

Notes: $a, b, c$ denotes significance at $1 \%, 5 \%$ and $10 \%$ level, respectively; standard errors in parentheses; controls: Hist. Popul.: historical population in $t=1939,1950,1961,1970$; Human Capital: Share of intermediate and share of high-skilled workers; ln Area: logarithm of area of the region in $\mathrm{km}^{2}$; Region Types: 8 dummy-Variables for region types; Federal States: 7 dummies for (partly aggregated) Federal States. 
TABLE III

Growth of the Autobahn Net 1994 to 2008 (OLS Estimates for 326 West German Regions)

\begin{tabular}{|c|c|c|c|c|c|c|}
\hline \multicolumn{7}{|c|}{ Dependent variable: $\Delta_{94,08} \ln I_{r}$} \\
\hline & (1) & $(2)$ & $(3)$ & $(4)$ & $(5)$ & (6) \\
\hline \multirow{3}{*}{$\ln$ Autobahn $_{1994}$} & \multicolumn{6}{|c|}{ Specification A } \\
\hline & $-0.115^{a}$ & $-0.115^{a}$ & $-0.109^{a}$ & $-0.117^{a}$ & $-0.119^{a}$ & $-0.114^{a}$ \\
\hline & $(0.033)$ & $(0.033)$ & $(0.031)$ & $(0.034)$ & $(0.034)$ & $(0.034)$ \\
\hline \multirow[t]{2}{*}{ ln Empl.1994 } & -0.035 & -0.012 & 0.033 & 0.013 & 0.021 & $0.092^{c}$ \\
\hline & $(0.028)$ & $(0.033)$ & $(0.039)$ & $(0.036)$ & $(0.048)$ & $(0.051)$ \\
\hline \multirow[t]{2}{*}{ Adj. $R^{2}$} & 0.102 & 0.107 & 0.126 & 0.129 & 0.142 & 0.196 \\
\hline & \multicolumn{6}{|c|}{ Specification B } \\
\hline \multirow[t]{2}{*}{$\Delta_{37,94} \ln$ Autobahn } & $-0.089^{a}$ & $-0.084^{a}$ & $-0.079^{a}$ & $-0.082^{a}$ & $-0.076^{a}$ & $-0.070^{a}$ \\
\hline & $(0.026)$ & $(0.024)$ & $(0.023)$ & $(0.025)$ & $(0.025)$ & $(0.024)$ \\
\hline \multirow{2}{*}{$\Delta_{94,08} \ln \mathrm{Empl}}$. & -0.001 & 0.002 & 0.003 & 0.003 & 0.002 & -0.003 \\
\hline & $(0.004)$ & $(0.004)$ & $(0.003)$ & $(0.003)$ & $(0.004)$ & $(0.004)$ \\
\hline \multirow[t]{2}{*}{ Adj. $R^{2}$} & 0.048 & 0.059 & 0.094 & 0.092 & 0.104 & 0.166 \\
\hline & \multicolumn{6}{|c|}{ Specification C } \\
\hline \multirow[t]{2}{*}{$\% \Delta_{37,94}$ Autobahn } & $-0.084^{b}$ & $-0.081^{b}$ & $-0.073^{b}$ & $-0.072^{b}$ & $-0.070^{b}$ & $-0.062^{c}$ \\
\hline & $(0.037)$ & $(0.036)$ & $(0.035)$ & $(0.035)$ & $(0.035)$ & $(0.035)$ \\
\hline \multirow[t]{2}{*}{$\Delta_{94,08} \ln$ Empl. } & 0.001 & 0.003 & 0.004 & 0.004 & 0.003 & -0.001 \\
\hline & $(0.003)$ & $(0.003)$ & $(0.003)$ & $(0.003)$ & $(0.003)$ & $(0.003)$ \\
\hline Adj. $R^{2}$ & 0.023 & 0.045 & 0.073 & 0.071 & 0.088 & 0.159 \\
\hline
\end{tabular}

Notes: $a, b, c$ denotes significance at $1 \%, 5 \%$ and $10 \%$ level, respectively; standard errors in parentheses; for further notes and control variables in models (1) to (6), see Table II. 
TABLE IV

First-Stage Regression Results

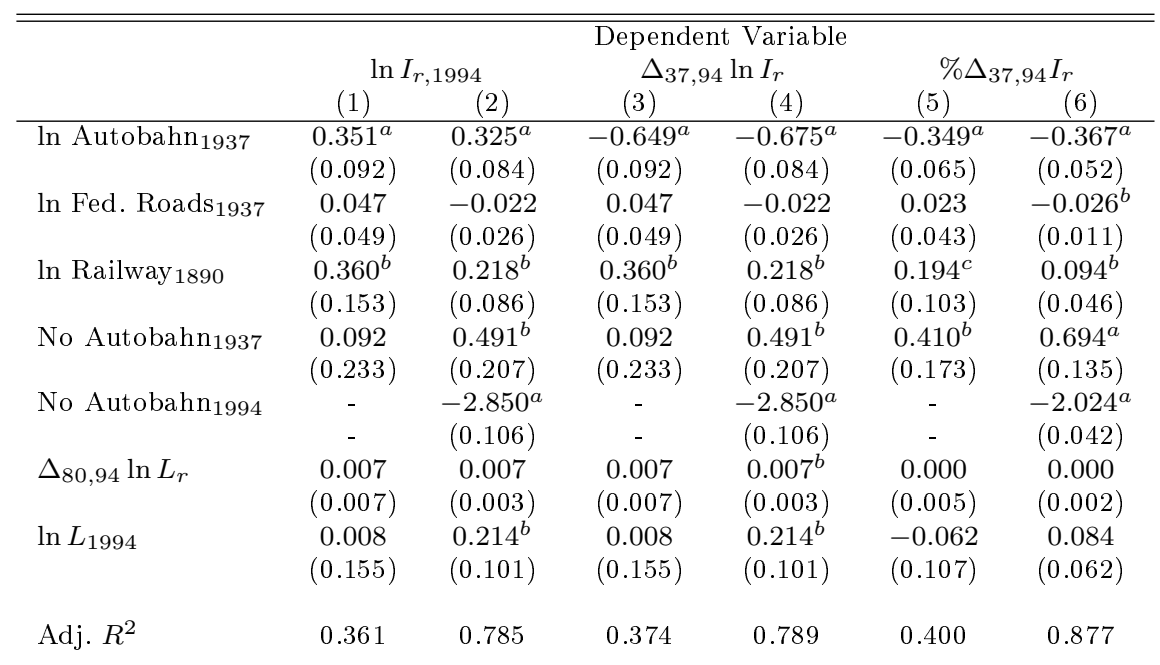

Notes: $a, b, c$ denotes significance at $1 \%, 5 \%$ and $10 \%$ level, respectively; standard errors in parentheses; No Autobahn 1937 and No Autobahn 1994 denote a $(0,1)$-dummy variable that takes the value of 1 if the region had no highway connection in 1937 and 1994, respectively; Further included instruments: historical population in $t=1939,1950,1961,1970$; Share of intermediate and high-skilled workers in total workforce, logarithm of area of the region in $\mathrm{km}^{2}$; 8 Dummy Variables for region types; 7 Dummies for (partly aggregated) Federal States. 
TABLE V

Employment Growth 1994 to 2008 and the Regional Autobahn Net (IV-Estimates for 326 West German Regions)

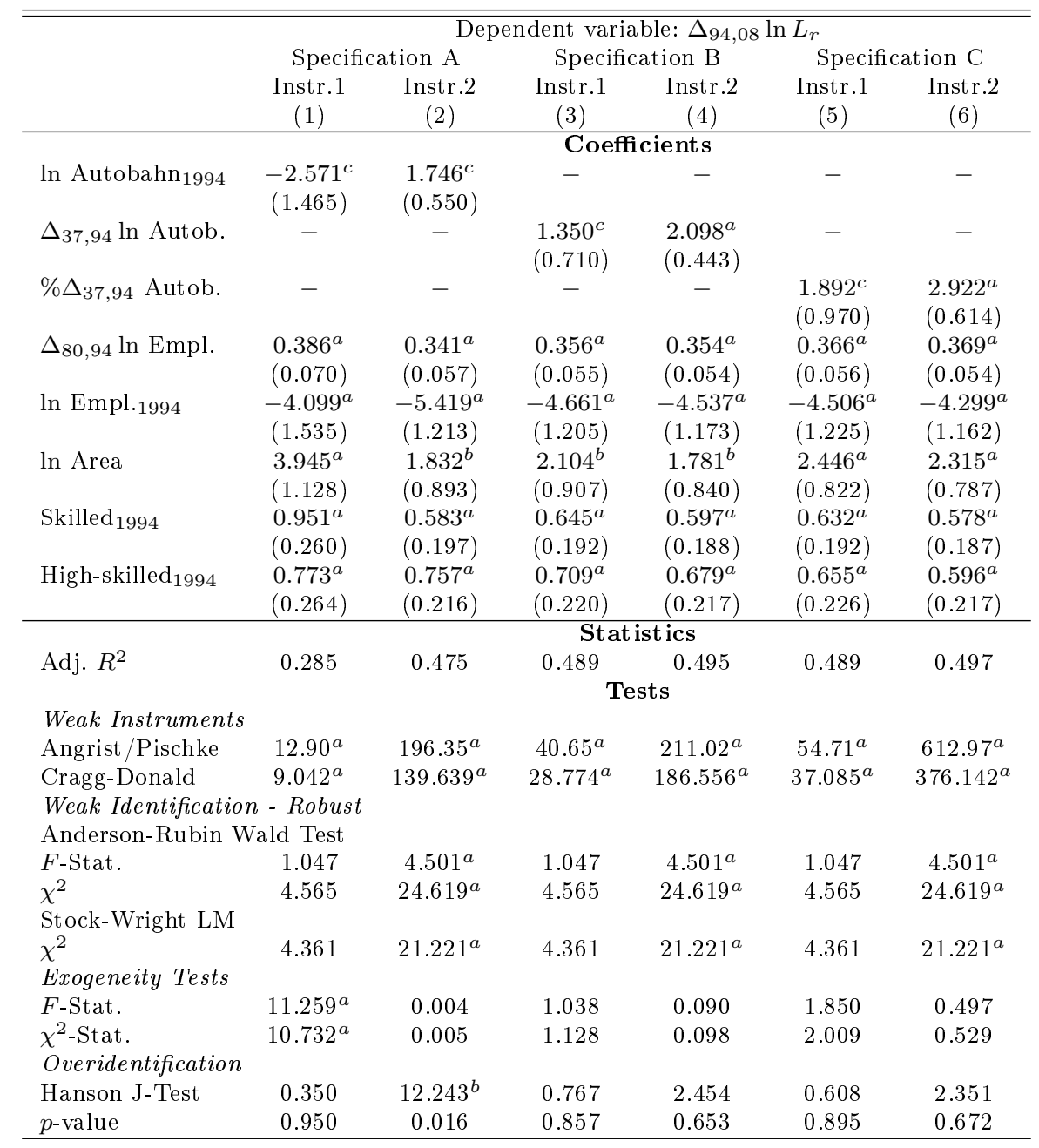

Notes: $a, b, c$ denotes significance at $1 \%, 5 \%$ and $10 \%$ level, respectively; standard errors in parentheses. All estimates include further control variables (historical population, regional type and federal state dummies as in the most comprehensive specification Table II). 
TABLE VI

Growth of the Regional Wage Bill 1994 to 2008 (OLS Estimates for 326 West German Regions)

\begin{tabular}{|c|c|c|c|c|c|c|}
\hline & \multicolumn{6}{|c|}{ Dependent Variable: $\Delta_{94,08} \ln \left(L_{r} \cdot W_{r}\right)$} \\
\hline & (1) & (2) & (3) & $(4)$ & (5) & (6) \\
\hline & \multicolumn{6}{|c|}{ Specification A } \\
\hline \multirow[t]{2}{*}{$\ln$ Autobahn 1994} & $1.247^{b}$ & $1.052^{c}$ & $1.112^{c}$ & $1.514^{a}$ & $1.845^{a}$ & $2.028^{a}$ \\
\hline & $(0.573)$ & $(0.570)$ & $(0.603)$ & $(0.584)$ & $(0.598)$ & $(0.596)$ \\
\hline \multirow[t]{2}{*}{ ln Wage Bill 1994} & $2.214^{b}$ & 1.044 & 0.163 & 1.273 & 2.799 & 2.810 \\
\hline & $(0.976)$ & $(1.064)$ & $(1.297)$ & $(1.412)$ & $(1.712)$ & $(1.788)$ \\
\hline \multirow[t]{2}{*}{$\Delta_{80,94} \ln$ Wage B. } & $0.456^{a}$ & $0.391^{a}$ & $0.384^{a}$ & $0.434^{a}$ & $0.396^{a}$ & $0.275^{a}$ \\
\hline & $(0.060)$ & $(0.080)$ & $(0.081)$ & $(0.071)$ & $(0.074)$ & $(0.083)$ \\
\hline \multirow[t]{2}{*}{ Adj. $R^{2}$} & 0.209 & 0.238 & 0.237 & 0.254 & 0.262 & 0.337 \\
\hline & \multicolumn{6}{|c|}{ Specification B } \\
\hline \multirow[t]{2}{*}{$\Delta_{37,94} \ln$ Autob. } & $2.206^{a}$ & $2.035^{a}$ & $2.143^{a}$ & $2.592^{a}$ & $2.555^{a}$ & $2.775^{a}$ \\
\hline & $(0.457)$ & $(0.473)$ & $(0.483)$ & $(0.491)$ & $(0.489)$ & $(0.478)$ \\
\hline \multirow[t]{2}{*}{ ln Wage Bill 1994} & $2.595^{a}$ & 1.451 & 0.425 & 1.999 & $3.500^{b}$ & $3.712^{b}$ \\
\hline & $(0.882)$ & $(0.981)$ & $(1.189)$ & $(1.332)$ & $(1.686)$ & $(1.713)$ \\
\hline \multirow[t]{2}{*}{$\Delta_{80,94} \ln$ Wage B. } & $0.467^{a}$ & $0.393^{a}$ & $0.387^{a}$ & $0.451^{a}$ & $0.419^{a}$ & $0.276^{a}$ \\
\hline & $(0.058)$ & $(0.078)$ & $(0.078)$ & $(0.067)$ & $(0.071)$ & $(0.080)$ \\
\hline \multirow[t]{2}{*}{ Adj. $R^{2}$} & 0.240 & 0.266 & 0.267 & 0.291 & 0.293 & 0.370 \\
\hline & \multicolumn{6}{|c|}{ Specification C } \\
\hline \multirow[t]{2}{*}{$\% \Delta_{37,94}$ Autob. } & $3.954^{a}$ & $3.778^{a}$ & $3.854^{a}$ & $4.207^{a}$ & $4.055^{a}$ & $4.405^{a}$ \\
\hline & $(0.703)$ & $(0.776)$ & $(0.788)$ & $(0.791)$ & $(0.782)$ & $(0.761)$ \\
\hline \multirow{2}{*}{ ln Wage Bill 1994} & $3.102^{a}$ & $2.033^{b}$ & 1.295 & $2.804^{b}$ & $3.742^{b}$ & $3.989^{b}$ \\
\hline & $(0.875)$ & $(0.982)$ & $(1.196)$ & $(1.359)$ & $(1.680)$ & $(1.684)$ \\
\hline \multirow[t]{2}{*}{$\Delta_{80,94} \ln$ Wage B. } & $0.490^{a}$ & $0.404^{a}$ & $0.402^{a}$ & $0.460^{a}$ & $0.431^{a}$ & $0.288^{a}$ \\
\hline & $(0.055)$ & $(0.073)$ & $(0.074)$ & $(0.065)$ & $(0.068)$ & $(0.079)$ \\
\hline Adj. $R^{2}$ & 0.259 & 0.283 & 0.282 & 0.301 & 0.300 & 0.379 \\
\hline
\end{tabular}

Notes: $a, b, c$ denotes significance at $1 \%, 5 \%$ and $10 \%$ level, respectively; standard errors in parentheses; for further notes and control variables in models (1) to (6) not reported here see Table II. 
TABLE VII

Growth of the Regional Wage Bill 1994 to 2008 (IV-Estimates for 326 West German Regions)

\begin{tabular}{|c|c|c|c|c|c|c|}
\hline & \multicolumn{6}{|c|}{ Dependent Variable: $\Delta_{94,08} \ln \left(L_{r} \cdot W_{r}\right)$} \\
\hline & \multicolumn{2}{|c|}{ Specification A } & \multicolumn{2}{|c|}{ Specification B } & \multicolumn{2}{|c|}{ Specification C } \\
\hline & $\begin{array}{l}\text { Instr.1 } \\
(1)\end{array}$ & $\begin{array}{l}\operatorname{Instr} .2 \\
(2)\end{array}$ & $\begin{array}{l}\text { Instr. } 1 \\
(3)\end{array}$ & $\begin{array}{l}\operatorname{Instr} .2 \\
(4)\end{array}$ & $\begin{array}{l}\text { Instr. } 1 \\
(5)\end{array}$ & $\begin{array}{l}\text { Instr.2 } \\
\quad(6)\end{array}$ \\
\hline & \multicolumn{6}{|c|}{ Coefficients } \\
\hline $\ln$ Autobahn $_{1994}$ & $\begin{array}{c}-5.496^{a} \\
(1.889)\end{array}$ & $\begin{array}{l}2.132^{a} \\
(0.709)\end{array}$ & - & - & - & - \\
\hline$\Delta_{37,94} \ln$ Autob. & - & - & $\begin{array}{l}2.292^{b} \\
(0.940)\end{array}$ & $\begin{array}{l}3.094^{a} \\
(0.595)\end{array}$ & - & - \\
\hline$\% \Delta_{37,94}$ Autob. & - & - & - & - & $\begin{array}{c}3.093^{b} \\
(1.246)\end{array}$ & $\begin{array}{l}4.264^{a} \\
(0.816)\end{array}$ \\
\hline$\Delta_{80,94} \ln$ Wage B. & $\begin{array}{l}0.327^{a} \\
(0.101)\end{array}$ & $\begin{array}{l}0.275^{a} \\
(0.081)\end{array}$ & $\begin{array}{l}0.278^{a} \\
(0.078)\end{array}$ & $\begin{array}{l}0.275^{a} \\
(0.077)\end{array}$ & $\begin{array}{l}0.288^{a} \\
(0.078)\end{array}$ & $\begin{array}{l}0.288^{a} \\
(0.076)\end{array}$ \\
\hline ln Wage Bill 1994 & $\begin{array}{l}4.930^{b} \\
(2.099)\end{array}$ & $\begin{array}{c}2.781 \\
(1.716)\end{array}$ & $\begin{array}{l}3.654^{b} \\
(1.668)\end{array}$ & $\begin{array}{l}3.750^{b} \\
(1.654)\end{array}$ & $\begin{array}{l}3.808^{b} \\
(1.656)\end{array}$ & $\begin{array}{c}3.969^{b} \\
(1.624)\end{array}$ \\
\hline $\ln$ Area & $\begin{array}{l}1.550^{a} \\
(1.677)\end{array}$ & $\begin{array}{l}-2.304^{c} \\
(1.262)\end{array}$ & $\begin{array}{l}-2.154^{c} \\
(1.274)\end{array}$ & $\begin{array}{l}-2.479^{b} \\
(1.201)\end{array}$ & $\begin{array}{l}-1.516 \\
(1.172)\end{array}$ & $\begin{array}{l}-1.625 \\
(1.140)\end{array}$ \\
\hline Skilled $_{1994}$ & $\begin{array}{c}0.909^{b} \\
(0.369)\end{array}$ & $\begin{array}{c}0.243 \\
(0.288)\end{array}$ & $\begin{array}{c}0.288 \\
(0.269)\end{array}$ & $\begin{array}{c}0.238 \\
(0.273)\end{array}$ & $\begin{array}{c}0.279 \\
(0.267)\end{array}$ & $\begin{array}{c}0.222 \\
(0.270)\end{array}$ \\
\hline High-skilled 1994 & $\begin{array}{c}0.464 \\
(0.410) \\
\end{array}$ & $\begin{array}{c}0.439 \\
(0.338) \\
\end{array}$ & $\begin{array}{l}0.365 \\
(0.335) \\
\end{array}$ & $\begin{array}{c}0.337 \\
(0.333) \\
\end{array}$ & $\begin{array}{c}0.287 \\
(0.337) \\
\end{array}$ & $\begin{array}{c}0.228 \\
(0.330) \\
\end{array}$ \\
\hline & \multicolumn{6}{|c|}{ Statistics } \\
\hline Adj. $R^{2}$ & \multicolumn{6}{|c|}{ Tests } \\
\hline \multicolumn{7}{|l|}{ Weak Instruments } \\
\hline Angrist/Pischke & $13.323^{a}$ & $196.097^{a}$ & $40.352^{a}$ & $207.547^{a}$ & $55.212^{a}$ & $615.134^{a}$ \\
\hline Cragg-Donald & $9.262^{a}$ & $139.309^{a}$ & $28.654^{a}$ & $185.222^{a}$ & $37.453^{a}$ & $379.513^{a}$ \\
\hline \multicolumn{7}{|c|}{$\begin{array}{l}\text { Weak Identification - Robust } \\
\text { Anderson-Rubin Wald Test }\end{array}$} \\
\hline F-Stat. & $3.235^{b}$ & $6.340^{a}$ & $3.235^{b}$ & $6.340^{a}$ & $3.235^{b}$ & $6.340^{a}$ \\
\hline $\begin{array}{l}\chi^{2} \\
\text { Stock-Wright LM }\end{array}$ & $11.838^{b}$ & $29.181^{a}$ & $11.838^{b}$ & $29.181^{a}$ & $11.838^{b}$ & $29.181^{a}$ \\
\hline $\begin{array}{l}\chi^{2} \\
\text { Exogeneity Tests }\end{array}$ & $11.838^{b}$ & $29.181^{a}$ & $11.838^{b}$ & $29.181^{a}$ & $11.838^{b}$ & $29.181^{a}$ \\
\hline$F$-Stat. & $22.567^{a}$ & 0.061 & 0.290 & 0.859 & 1.361 & 0.251 \\
\hline $\begin{array}{l}\chi^{2} \text {-Stat. } \\
\text { Overidentification }\end{array}$ & $19.804^{a}$ & 0.066 & 0.313 & 0.953 & 1.463 & 0.269 \\
\hline Hanson J-Test & 0.255 & $22.050^{a}$ & 6.417 & 7.338 & 6.480 & 7.658 \\
\hline$p$-value & 0.968 & 0.000 & 0.093 & 0.119 & 0.090 & 0.105 \\
\hline
\end{tabular}

Notes: $a, b, c$ denotes significance at $1 \%, 5 \%$ and $10 \%$ level, respectively; standard errors in parentheses. All estimates include further control variables (historical population, regional type and federal state dummies as in the most comprehensive specification Table II). 
TABLE VIII

The Impact of Regional Transport Infrastructure on Regional Employment and the Wage Bill for Different Estimation Methods

\begin{tabular}{|c|c|c|c|c|c|c|}
\hline \multirow[b]{3}{*}{ Method } & \multicolumn{6}{|c|}{ A. Employment Growth } \\
\hline & \multicolumn{3}{|c|}{ Instruments 1} & \multicolumn{3}{|c|}{ Instruments 2} \\
\hline & Coeff. & $z$-Stat. & Impact & Coeff. & $z$-Stat. & Impact \\
\hline & \multicolumn{6}{|c|}{ Specification A } \\
\hline OLS & 1.765 & 3.836 & 2.421 & 1.765 & 3.836 & 2.421 \\
\hline 2SLS & - & - & - & 1.746 & 3.661 & 2.395 \\
\hline GMM-rob. & - & - & - & 1.853 & 3.387 & 2.541 \\
\hline \multirow[t]{2}{*}{ LIML-rob. } & - & - & - & 1.744 & 3.105 & 2.393 \\
\hline & \multicolumn{6}{|c|}{ Specification B } \\
\hline OLS & 2.028 & 5.664 & 2.829 & 2.028 & 5.664 & 2.829 \\
\hline 2SLS & 1.350 & 2.010 & 1.884 & 2.098 & 5.185 & 2.927 \\
\hline GMM-rob. & 1.356 & 1.923 & 1.892 & 2.077 & 4.705 & 2.897 \\
\hline \multirow[t]{2}{*}{ LIML-rob. } & 1.341 & 1.871 & 1.871 & 2.099 & 4.719 & 2.928 \\
\hline & \multicolumn{6}{|c|}{ Specification C } \\
\hline OLS & 3.074 & 5.333 & 2.982 & 3.074 & 5.333 & 2.982 \\
\hline 2SLS & 1.892 & 2.076 & 1.835 & 2.922 & 5.212 & 2.833 \\
\hline GMM-rob. & 1.917 & 1.987 & 1.859 & 2.911 & 4.760 & 2.823 \\
\hline \multirow[t]{3}{*}{ LIML-rob. } & 1.882 & 1.929 & 1.825 & 2.920 & 4.749 & 2.832 \\
\hline & \multicolumn{6}{|c|}{ B. Wage Bill } \\
\hline & \multicolumn{3}{|c|}{ Instruments 1} & \multicolumn{3}{|c|}{ Instruments 2} \\
\hline \multirow[t]{2}{*}{ Method } & Coeff. & $z$-Stat. & Impact & Coeff. & $z$-Stat. & Impact \\
\hline & \multicolumn{6}{|c|}{ Specification A } \\
\hline OLS & 2.028 & 3.401 & 2.783 & 2.028 & 3.401 & 2.783 \\
\hline 2SLS & - & - & - & 2.132 & 3.108 & 2.925 \\
\hline GMM-rob. & - & - & - & 2.040 & 2.889 & 2.798 \\
\hline \multirow[t]{2}{*}{ LIML-rob. } & - & - & - & 2.144 & 2.925 & 2.942 \\
\hline & \multicolumn{6}{|c|}{ Specification B } \\
\hline OLS & 2.775 & 5.809 & 3.872 & 2.775 & 5.809 & 3.872 \\
\hline 2SLS & 2.292 & 2.388 & 3.197 & 3.094 & 5.331 & 4.316 \\
\hline GMM-rob. & 2.274 & 2.474 & 3.173 & 3.015 & 5.088 & 4.206 \\
\hline \multirow[t]{2}{*}{ LIML-rob. } & 2.262 & 2.306 & 3.156 & 3.102 & 5.182 & 4.328 \\
\hline & \multicolumn{6}{|c|}{ Specification C } \\
\hline OLS & 4.405 & 5.788 & 4.272 & 4.405 & 5.788 & 4.272 \\
\hline 2SLS & 3.093 & 2.401 & 2.999 & 4.264 & 5.351 & 4.135 \\
\hline GMM-rob. & 3.121 & 2.541 & 3.027 & 4.172 & 5.135 & 4.046 \\
\hline LIML-rob. & 3.026 & 2.349 & 2.935 & 4.261 & 5.207 & 4.132 \\
\hline
\end{tabular}

Notes: TSLS: 2-Stage Least Squares, GMM-rob.: Generalized Method of Moments, estimates efficient for arbitrary heteroskedasticity and statistics robust to heteroskedasticity;

LIML-rob.: Limited Maximum Likelihood Estimator, estimates efficient for arbitrary heteroskedasticity and statistics robust to heteroskedasticity; "Impact" is the effect of a one standard deviation increase of the respective endogenous infrastructure variable; Instruments 1 (2): specification excluding (including) a (0,1)-dummy variable for no autobahn in 1994. 